Original Research Paper

\title{
Performance Assessment of Solar Chimneys: Part 2 - Impacts of Slenderness Value and Collector Slope on Power Output
}

\author{
${ }^{1,2}$ Erdem Cuce and ${ }^{2,3}$ Pinar Mert Cuce \\ ${ }^{I}$ Department of Mechanical Engineering, \\ Faculty of Engineering, Recep Tayyip Erdogan University, Zihni Derin Campus, 53100 Rize, Turkey \\ ${ }^{2}$ Low/Zero Carbon Energy Technologies Laboratory, \\ Faculty of Engineering, Recep Tayyip Erdogan University, Zihni Derin Campus, 53100 Rize, Turkey \\ ${ }^{3}$ Department of Energy Systems Engineering, \\ Faculty of Engineering, Recep Tayyip Erdogan University, Zihni Derin Campus, 53100 Rize, Turkey
}

Article history

Received: 03-07-2019

Revised: 06-07-2019

Accepted: 8-07-2019

Corresponding Author:

Erdem Cuce

Department of Mechanical

Engineering, Faculty of

Engineering, Recep Tayyip

Erdogan University, Zihni

Derin Campus, 53100 Rize,

Turkey

Tel: +90 $4642237518-1152$

Fax: +90 4642237514

Email: erdem.cuce@erdogan.edu.tr

\section{Introduction}

Solar energy is believed in having the greatest potential among the other renewable energy technologies in order to compete with fossil fuel based energy sources (Cuce et al., 2018). It is easy to underline that solar energy has numerous applications covering solar electricity, solar thermal and conventional or concentrating cogeneration technologies (Daneshazarian et al., 2017). Solar electricity, which is dominated by Photovoltaic (PV) modules, is in the centre of interest worldwide as a consequence of notable advancements in semiconductor material technologies and enhancements in energy and

\begin{abstract}
In the previous part, impacts of chimney height thus pressure difference on the power output of solar chimneys have been numerically evaluated. Within the scope of this research, slenderness and slope of collector are analysed in terms of their potential influence on average velocity of air at the chimney inlet. The analyses are based on a commercial considered to be $100 \mathrm{~m}$ in the research and the chimney diameter is varied through a dimensionless parameter $(\beta)$. Basically, $\beta$ is defined as inverse slenderness and its value of 0.1 corresponds to a chimney diameter of $10 \mathrm{~m}$ as expected. Average velocity of air at the chimney inlet is numerically assessed for the $\beta$ values in the range of 0.1-0.5. Collector slope is also investigated in the analyses through a dimensionless parameter $(\delta)$. The term $\delta$ is defined as the ratio of inlet height of collector to the collector height at the centre. Similarly, average velocity of air at the chimney inlet is determined for the $\delta$ values in the range of 0.2-1.0. The analyses are conducted for a constant solar intensity of $200 \mathrm{~W} / \mathrm{m}^{2}$. The chimney height at the centre is taken to be $4 \mathrm{~m}$ in the slenderness analyses and $10 \mathrm{~m}$ in the collector slope assessments. The height of collector inlet is constant and 1 $\mathrm{m}$ in the slenderness research. On the other hand, it is varied from 2 to $10 \mathrm{~m}$ in the collector slope analyses. The results reveal that the velocity figures exponentially decrease from 15.93 to $11.85 \mathrm{~m} / \mathrm{s}$ when the $\beta$ value rises from 0.1 to 0.5 . On the contrary, velocity figures increase with increasing $\delta$
\end{abstract}

Keywords: Solar Chimney, Chimney Height, Pressure Difference, Average Velocity, Power Output exergy efficiencies of PV modules (Cuce et al., 2019). However, solar electricity based on PVs has some shortcomings. For instance, payback period and overall system performance of such systems highly depend on operational parameters and environmental conditions. For the climatic regions with abundant solar radiation, PVs are found to be feasible whereas they are not considered to be an optimum clean energy generation technology for the areas with lower solar energy potential. From this point of view, alternative energy technologies are investigated like solar chimneys which are capable of producing electricity at a desirable efficiency range regardless of climatic parameters (Schlaich, 1996). 


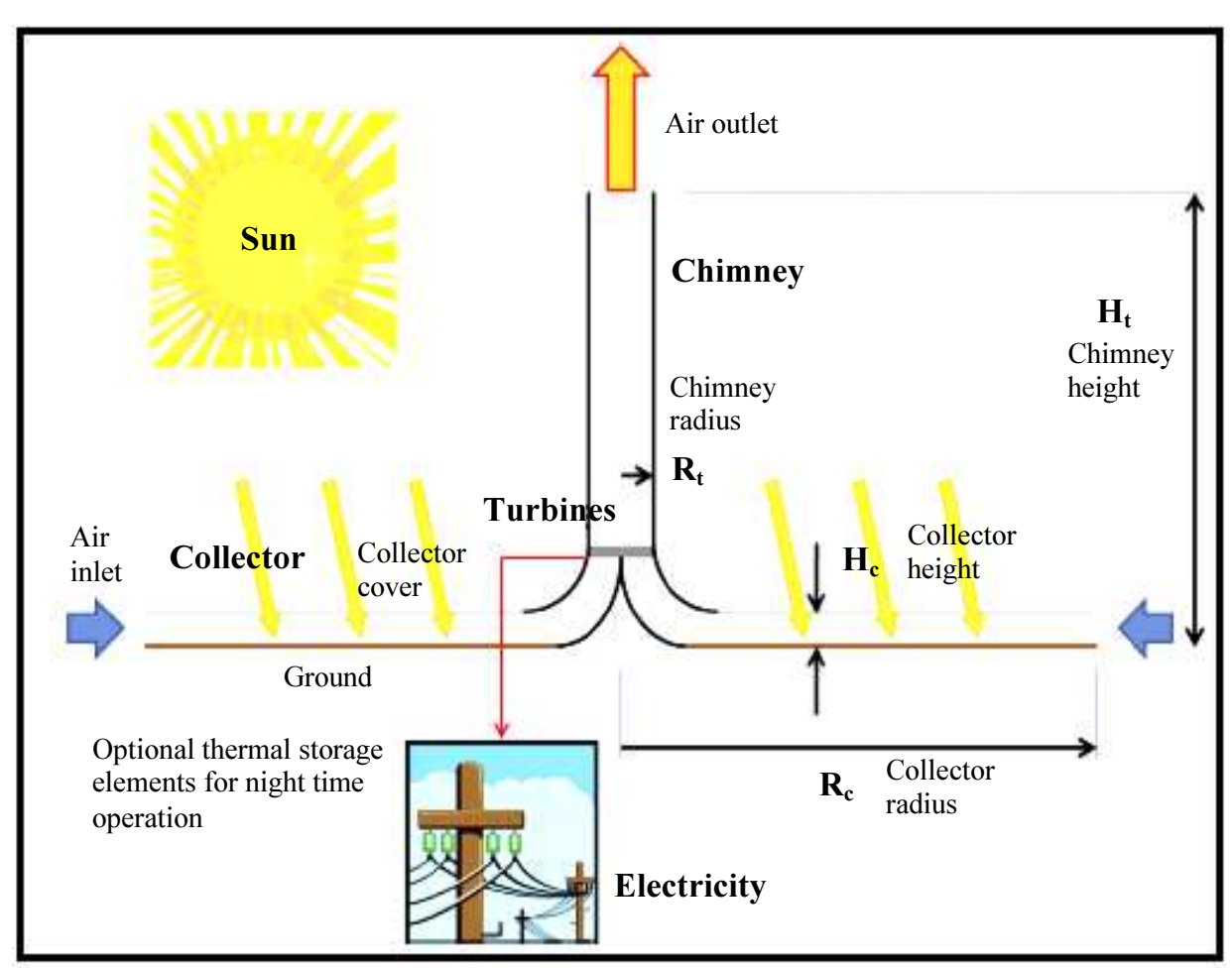

Fig. 1: Schematic of a typical solar chimney power plant (Toghraie et al., 2018)

A typical solar chimney shown in Figure 1 has basically three main parts as chimney, turbine and collector. The chimney, which is essentially a massive pressure tower, is the core of the entire system. A remarkable pressure difference occurs between the inlet and outlet sections of chimney depending on the chimney height which results in electricity generation in winter and summer irrespective of environmental conditions. Adiabatic conditions are assumed to take place on the outer surfaces of chimneys since such systems are usually constructed by thermally insulative materials (Toghraie et al., 2018). On the other hand, collectors in solar chimneys are usually made of transparent materials such as polythene or glass to be able to improve the greenhouse effect beneath the collectors. The greenhouse effect speeds air up and air turns the turbine which is mounted at the centre of the collector at a certain height (Fasel et al., 2013). The ground of solar chimneys can be used for agricultural purposes and by doing so excessive thermal energy is stored on the ground. This energy then can be used to improve the night time performance of solar chimneys (Amudam and Chandramohan, 2019).

When the working principle of solar chimneys is gone through, it is not difficult to assert that chimney height should be maximum to be able to maximise the power output of plant (Zhou et al., 2009). However, solar chimneys are very costly constructions and this handicap limits the experimental investigation of solar chimneys. Therefore, in most cases, analyses are conducted on numerical or theoretical basis. Chimney height is of vital importance in terms of power output in solar chimney designs. Buoyancy effects are enhanced with the chimney height which yield to greater velocity figures at the inlet section of the chimney. However, wind effects also get strong with the increasing altitudes and hence geometric optimisation of solar chimneys becomes much more important (Guo et al., 2019).

In the design of chimney, collector area is of vital importance as it directly influences the greenhouse effect and thus the air acceleration. Instead of a naked analysis of chimney height in the system designs, a term called slenderness is utilised which combines the cumulative impacts of chimney height and chimney diameter. The slenderness of a solar chimney power plant is expressed as the ratio of chimney height to chimney diameter. In practice, the slenderness takes a value in the range of 515 and optimum case is reported to be 12 through the literature not to encounter destroying wind effects (Kashiwa and Kashiwa, 2008). For the lower slenderness values, cold air inflow to the chimney is inevitable which reduces the system performance (Pretorius, 2007). Ambient cross wind effects, which notably enhance the power output of solar chimneys, are considerably improved with increasing chimney height as reported in another research (Ming et al., 2017). In some designs of solar chimneys, the slenderness value is asserted to be 10 for maximum air velocity near the turbine inlet 
(Kasaeian et al., 2017). However, it needs to be noted that optimum slenderness depends on multiple parameters covering material properties, climatic conditions, thermal energy storage option on the ground, slope of collector, thermal resistance of chimney, etc.

It is not difficult to emphasise through the literature that the chimney height greatly affects the efficiency of solar chimney power plant since the pressure difference between chimney inlet and outlet is remarkably influenced by the height of chimney (Lal et al., 2016). From this point of view, chimney efficiency is correlated with the chimney height via numerical models as proposed by Dai et al. (2003). Cuce and Cuce (2019) also develops statistical correlations between the chimney height and maximum average air velocity at the chimney inlet. He reports that air velocity exponentially increases with the chimney height.

Current numerical models and empirical correlations of solar chimney power plants yield successful outputs in most cases, however, it is unequivocal that overall performance of a solar chimney power plant also depends on other geometric parameters such as slenderness and collector slope. Within the scope of this research, slope of collector and slenderness are investigated in terms of their probable effects on average velocity of air near the turbine inlet. A 2D model is considered in the CFD analyses carried out in ANSYS FLUENT. Steady-state conditions are taken into account for a constant solar intensity of 200 $\mathrm{W} / \mathrm{m}^{2}$ and ambient temperature of $300 \mathrm{~K}$.

\section{Solar Chimney Power Plant}

A typical solar chimney design is considered in the CFD research and the impacts of slenderness and collector slope on maximum average air velocity at the chimney inlet are numerically analysed. The research is split into two parts. In the first part, for a constant chimney height $(100 \mathrm{~m})$, the chimney diameter is varied over a dimensionless geometric parameter $(\beta)$. Basically, $\beta$ is expressed as inverse slenderness and its value of 0.1 corresponds to a chimney diameter of $10 \mathrm{~m}$. Maximum average velocity of air near the turbine inlet is numerically determined for the $\beta$ values in the range of 0.1-0.5. The height of air vent at the inlet is selected to be $1 \mathrm{~m}$ whereas the collector height at the centre is $4 \mathrm{~m}$. In the second part of the analyses, collector slope is assessed through another dimensionless parameter $(\delta)$. The term $\delta$ is described as the ratio of inlet height of collector to the collector height at the centre. For five different values of $\delta$ in the range of 0.2-1.0, maximum average velocity of air at the chimney inlet is numerically determined. In the second part, the height of collector inlet is taken to be $2 \mathrm{~m}$, whereas it is $10 \mathrm{~m}$ at the collector centre. Collector radius is assumed to me $500 \mathrm{~m}$ for both cases. Pressure inlet condition is selected at the inlet of air vents in the CFD analyses while pressure outlet is adopted at the chimney outlet to be able to consider the actual pressure drop by chimney height.

\section{CFD Analyses of Solar Chimney Power Plant}

ANSYS FLUENT is a reliable and effective CFD software for the numerical performance assessment of solar chimney power plants. For different values of inverse slenderness and collector slope, average air velocity at the chimney inlet is numerically determined by implementing $\mathrm{k}-\varepsilon$ turbulence model, continuity, momentum and energy equations for a $2 \mathrm{D}$ model. To be able to model the natural convection inside the air medium beneath the collector, air is selected as ideal gas. PRESTO approach, which is based on pressure-based solver, is adopted for accurate modelling of heat and momentum transfer within the air medium. Mesh-independent solutions are achieved for each case. Continuity, momentum and energy equations are solved with convergence criteria of $10^{-6}$ through a quadratic mesh option. Convergence is provided by the successful control of under-relaxation factors throughout the iteration process. Specific heat capacity, density and thermal conductivity of external air are assumed to be 1006.43 $\mathrm{J} / \mathrm{kgK}, 1.225 \mathrm{~kg} / \mathrm{m}^{3}$ and $0.0242 \mathrm{~W} / \mathrm{mK}$, respectively.

\section{Results and Discussion}

Within the scope of the first part, maximum average velocity of air at the chimney inlet is numerically determined for five different values of inverse slenderness $(\beta=0.1,0.2,0.3,0.4$ and 0.5$)$. Collector radius and chimney height are taken to be 500 and 100 $\mathrm{m}$, respectively. For a constant solar radiation of 200 $\mathrm{W} / \mathrm{m}^{2}$, velocity contours and corresponding velocity figures are obtained as shown in Fig. 2. It is understood from the numerical results that the velocity figures are considerably affected by the inverse slenderness. The mathematical correlation between the air velocity and inverse slenderness is given in Fig. 3. For $\beta=0.1$, which corresponds to a chimney height of $100 \mathrm{~m}$ and chimney diameter of $10 \mathrm{~m}$, average velocity at the chimney inlet is found to be $15.93 \mathrm{~m} / \mathrm{s}$. On the other hand, for $\beta=0.2$, in other words when chimney diameter is increased to 20 $\mathrm{m}$, the average velocity reduces to $11.39 \mathrm{~m} / \mathrm{s}$. The reduction in air velocity is calculated to be $28.49 \%$. It is concluded from the relationship between the air velocity and inverse slenderness that both exponential and linear effects take place in the correlation. The correlation coefficient is determined to be 0.996 , which is highly acceptable. After a certain value of inverse slenderness, air velocity at the chimney inlet shows a rising tendency. However, it is easy to assert that greater performance figures are expected to be achieved with lower inverse slenderness values. 


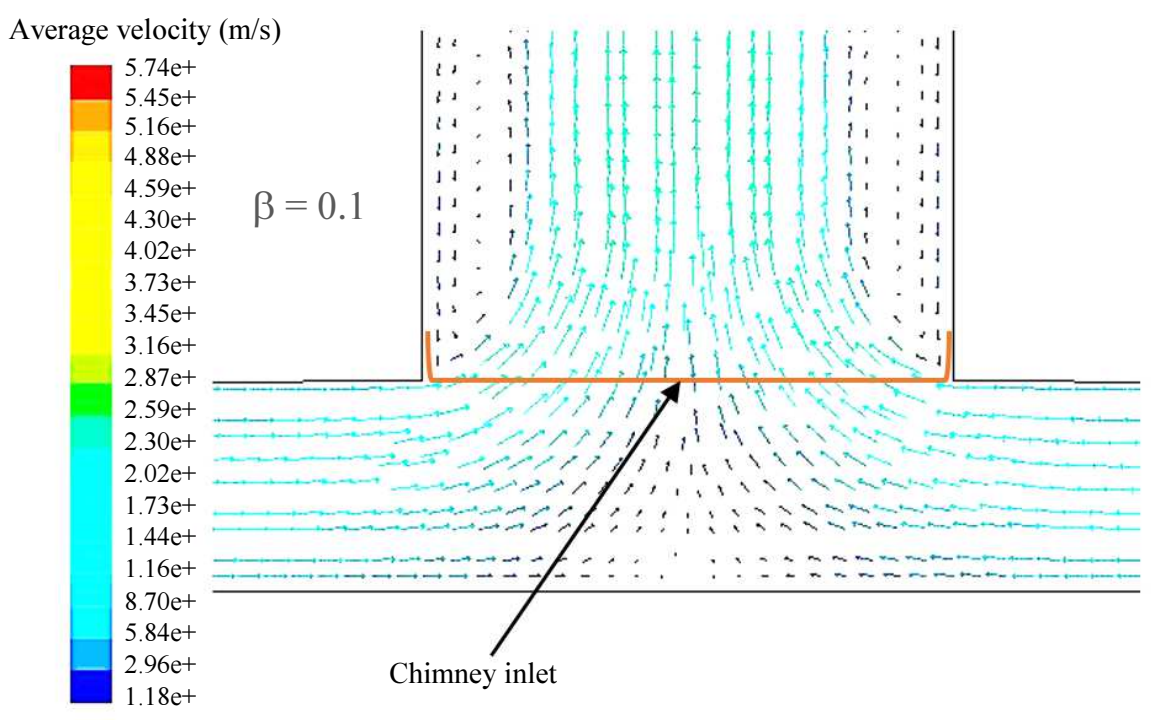

Velocity vectors colored by velocity magnitude $(\mathrm{m} / \mathrm{s})$

May 30, 2014

FLUENT 6.3 (2d, dp, pbns, rke)

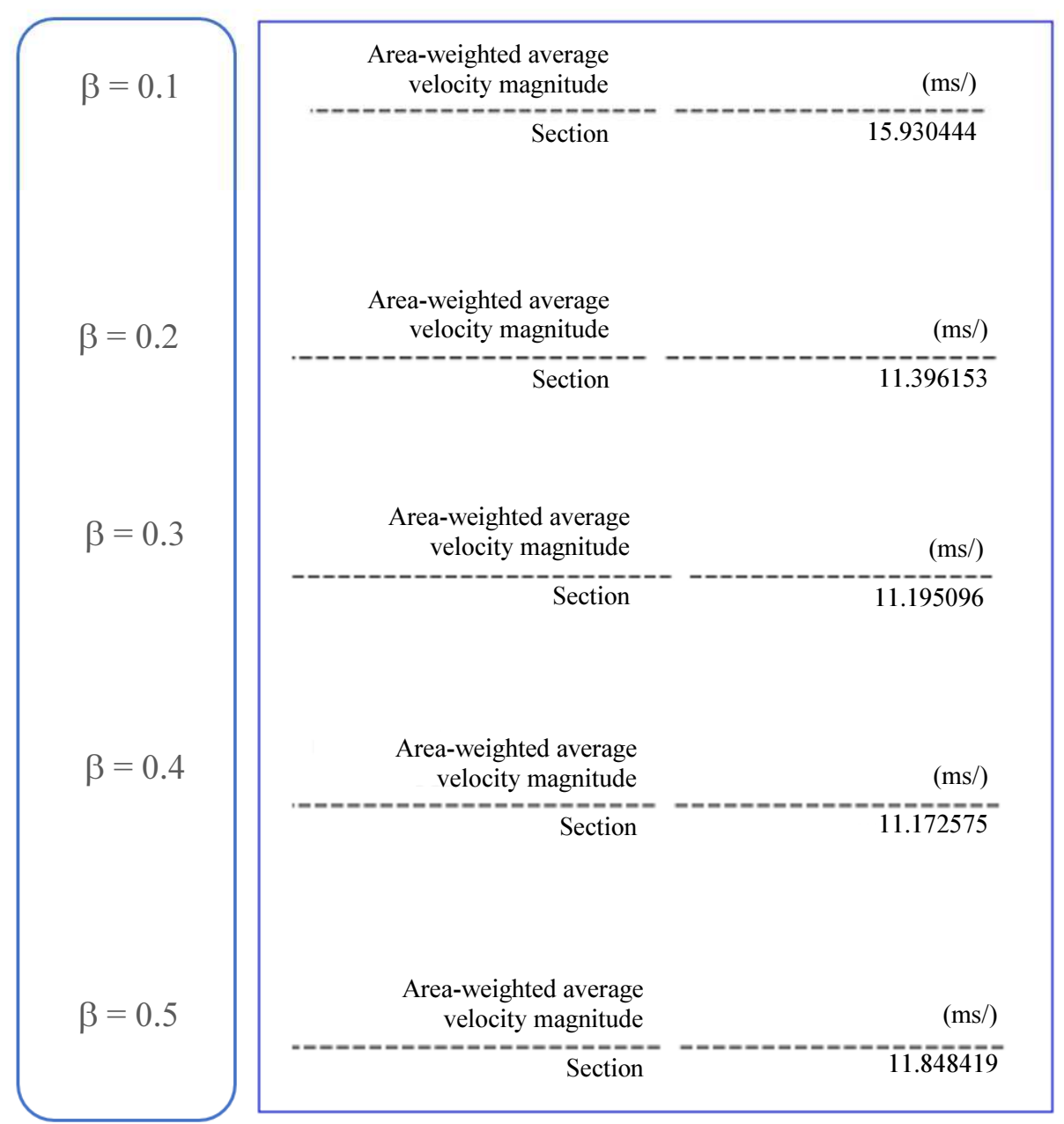

Fig. 2: Average velocity of air at the chimney inlet for different inverse slenderness values 


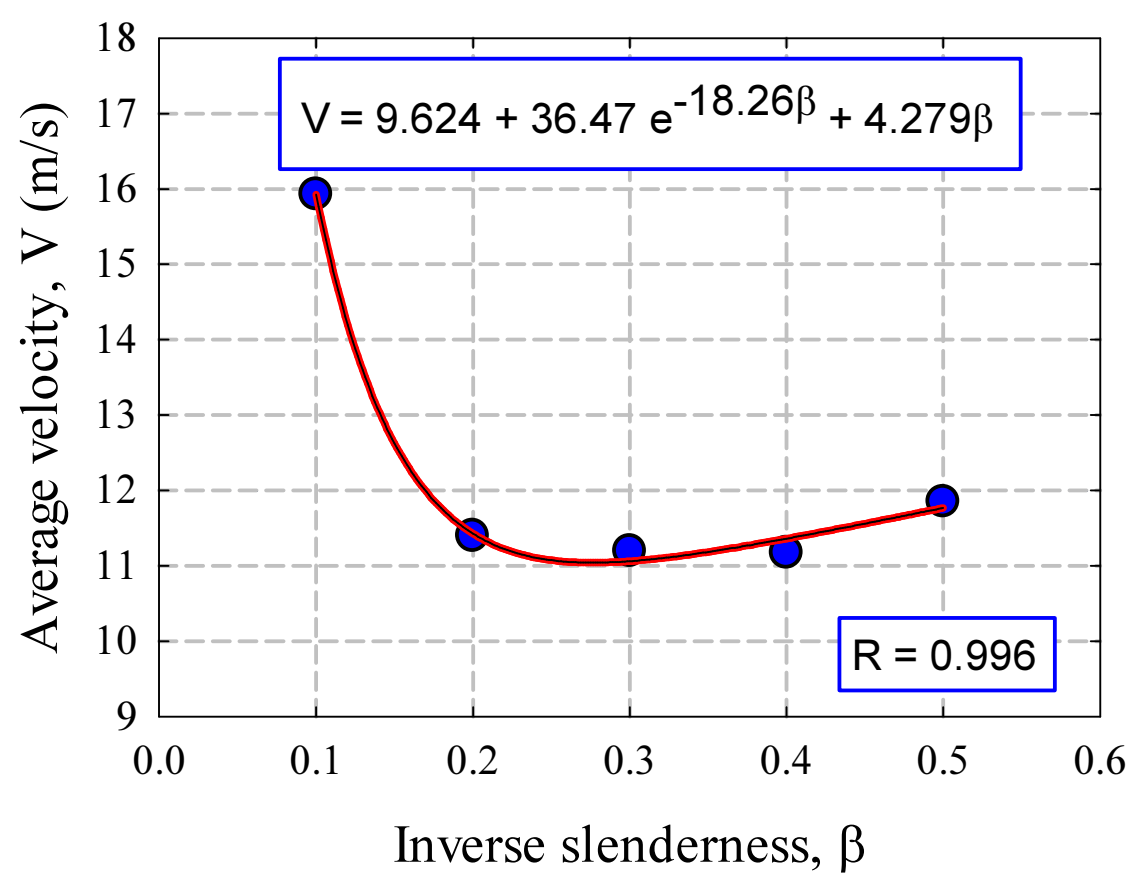

Fig. 3: Average velocity of air as a function of inverse slenderness.
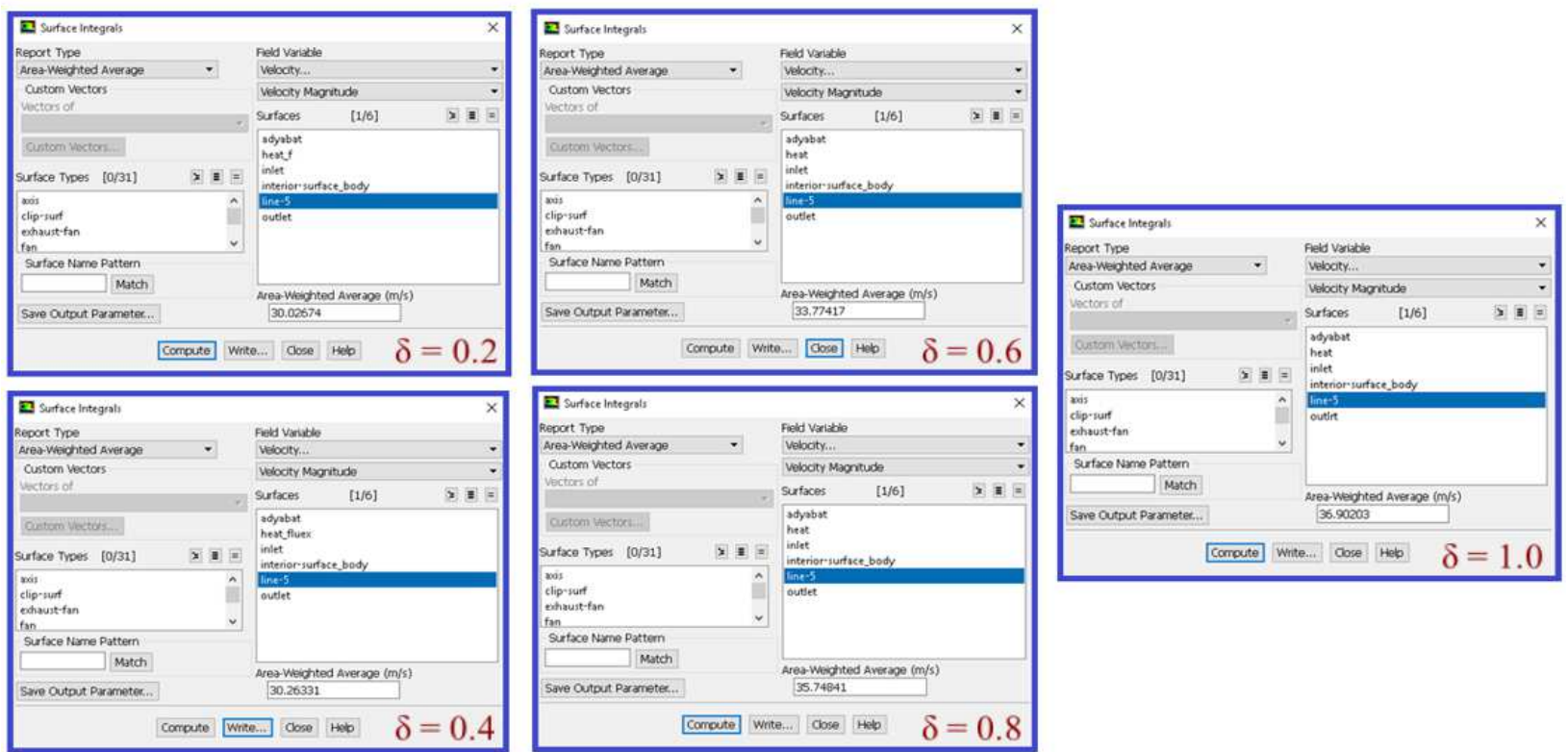

Fig. 4: Average velocity of air for different collector slopes

In the second part of the analyses, maximum average velocity of air at the chimney inlet is numerically determined for five different values of collector slope $(\delta=$ $0.2,0.4,0.6,0.8$ and 1.0). Chimney height and collector radius are taken to be 100 and $500 \mathrm{~m}$, respectively similar to the first part. Corresponding velocity figures toward different collector slopes are achieved as shown in Fig. 4. It is concluded from the results that there is almost no change in the velocity figures when $\delta$ value is increased from 0.2 to 0.4 . however, there is a linear increase after that value up to $\delta=1.0$, which corresponds to horizontal collector without any slope. The mathematical relationship between average velocity at the chimney inlet and collector slope is presented in Fig. 5. A linear relationship is observed between air velocity and collector slope with a correlation coefficient of 0.95 . 


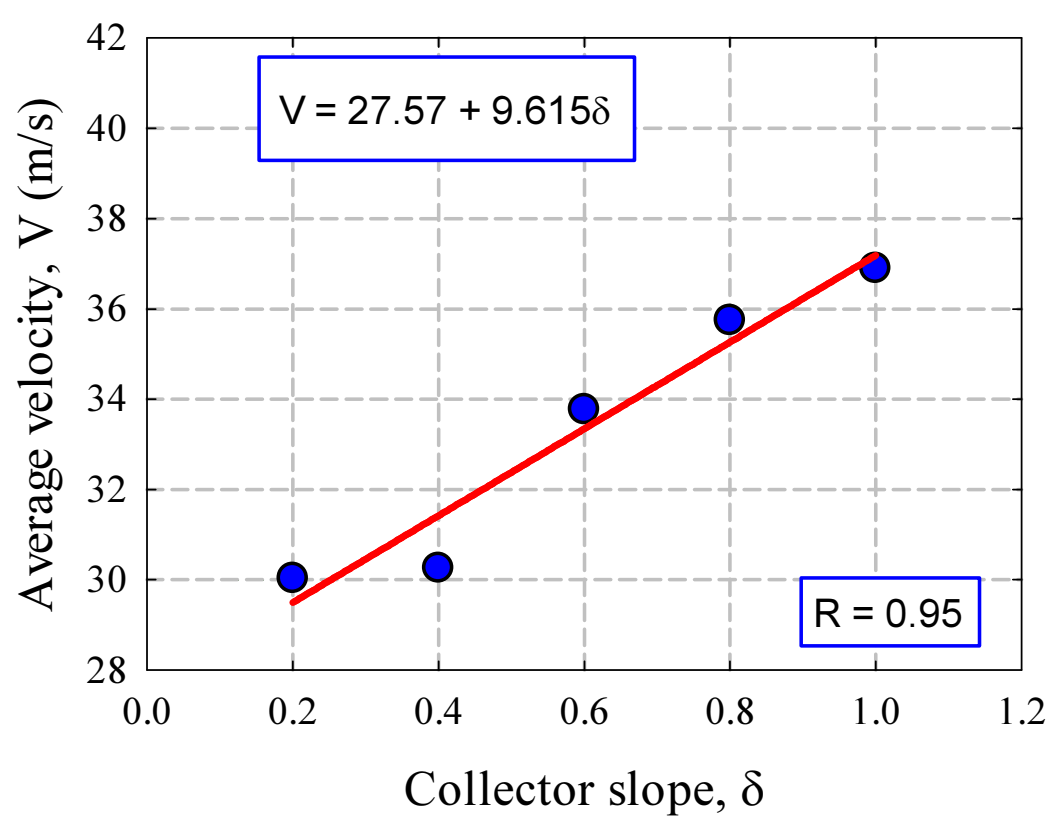

Fig. 5: Average velocity of air as a function of collector slope

\section{Conclusion}

The impacts of slenderness and collector slope on the average velocity of air at the chimney inlet are numerically investigated. The CFD analyses are carried out for five inverse slenderness values and for five collector slopes. For both cases, collector radius and chimney height are taken to be equal and 500 and $100 \mathrm{~m}$, respectively. The results are achieved for steady-state conditions under constant solar intensity of $200 \mathrm{~W} / \mathrm{m} 2$. Mathematical correlations are developed for each case to give an understanding for the effects of main geometric parameters on average velocity figures near the turbine inlet. Velocity figures are found to reduce remarkably with lower slenderness. For $\beta=0.1$, which corresponds to a chimney height of $100 \mathrm{~m}$ and chimney diameter of $10 \mathrm{~m}$, average velocity at the chimney inlet is found to be maximum and $15.93 \mathrm{~m} / \mathrm{s}$, which is in good accordance with literature. On the other hand, greater slenderness values have some shortcomings as such chimneys are under the risk of destroying wind effects. Horizontal collectors are found to yield better velocity values compared to cases with certain slopes. Overall, it needs to be noted that power output of solar chimneys is highly affected by geometric parameters. In this respect, further works should focus on geometric optimisation of such systems.

\section{Author's Contributions}

Erdem Cuce: Mentoring the research, revising/editing the body.

Pinar Mert Cuce: Preparation of the main draft following the collecting data and evaluating the findings.

\section{Ethics}

This article is original and contains unpublished material. The corresponding author confirms that all of the other authors have read and approved the manuscript and no ethical issues involved.

\section{References}

Amudam, Y. and V.P. Chandramohan, 2019. Influence of thermal energy storage system on flow and performance parameters of solar updraft tower power plant: A three dimensional numerical analysis. J. Cleaner Product., 207: 136-152. DOI: $10.1016 / j . j c l e p r o .2018 .09 .248$

Cuce, E. and P.M. Cuce, 2019. Performance assessment of solar chimneys: Part I - Impact of chimney height on power output. Energy Res. J., 10: 11-19.

Cuce, E., E.K. Oztekin and P.M. Cuce, 2018. Hybrid Photovoltaic/Thermal (HPV/T) systems: From theory to applications. Energy Res. J., 9: 1-71. DOI: 10.3844/erjsp.2018.1.71

Cuce, E., P.M. Cuce and T. Bali, 2019. Impact of humidity on current parameters of solar cells. J. Energy Syst., 2: 84-96. DOI: 10.30521/jes.441643

Dai, Y.J., H.B. Huang and R.Z. Wang, 2003. Case study of solar chimney power plants in Northwestern regions of China. Renewable Energy, 28: 1295-1304. DOI: $10.1016 / \mathrm{S} 0960-1481(02) 00227-6$

Daneshazarian, R., E. Cuce and P.M. Cuce, 2017. An overview of Concentrating Photovoltaic Thermal (CPVT) collectors. Energy Res. J., 8: 11-21. DOI: $10.3844 /$ erjsp.2017.11.21 
Fasel, H.F., F. Meng, E. Shams and A. Gross, 2013. CFD analysis for solar chimney power plants. Solar Energy, 98: 12-22.

DOI: 10.1016/j.solener.2013.08.029

Guo, P., T. Li, B. Xu, X. Xu and J. Li, 2019. Questions and current understanding about solar chimney power plant: A review. Energy Convers. Manage., 182: 21-33. DOI: 10.1016/j.enconman.2018.12.063

Kasaeian, A.B., S. Molana, K. Rahmani and D. Wen, 2017. A review on solar chimney systems. Renewable Sustainable Energy Rev., 67: 954-987. DOI: 10.1016/j.rser.2016.09.081

Kashiwa, B.A. and C.B. Kashiwa, 2008. The solar cyclone: A solar chimney for harvesting atmospheric water. Solar Energy, 33: 331-339. DOI: 10.1016/j.energy.2007.06.003

Lal, S., S.C. Kaushik and R. Hans, 2016. Experimental investigation and CFD simulation studies of a laboratory scale solar chimney for power generation. Sustainable Energy Technol. Assess., 13: 13-22. DOI: $10.1016 /$ j.seta.2015.11.005
Ming, T., Y. Wu, R.K. Richter, W. Liu and S.A. Sherif, 2017. Solar updraft power plant system: A brief review and a case study on a new system with radial partition walls in its collector. Renewable Sustainable Energy Rev., 69: 472-487. DOI: 10.1016/j.rser.2016.11.135

Pretorius, J.P., 2007. Optimization and control of a large-scale solar chimney power plant. Ph.D. Thesis, University of Stellenbosch.

Schlaich, J., 1996. The solar chimney: electricity from the sun. Edition Axel Menges.

Toghraie, D., A. Karami, M. Afrand and A. Karimipour, 2018. Effects of geometric parameters on the performance of solar chimney power plants. Energy, 162: 1052-1061.

DOI: 10.1016/j.energy.2018.08.086

Zhou, X., J. Yang, B. Xiao, G. Hou and F. Xing, 2009. Analysis of chimney height for solar chimney power plant. Applied Thermal Eng., 29: 178-185. DOI: 10.1016/j.applthermaleng.2008.02.014 